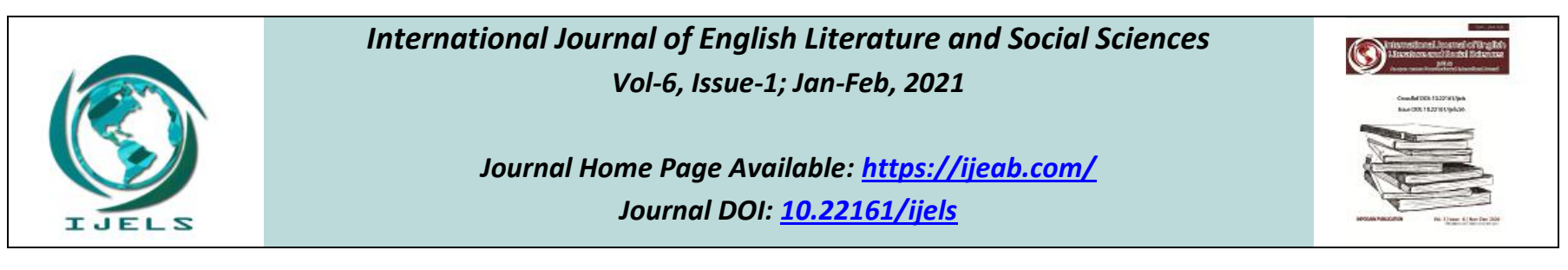

\title{
Child Birth Rites of Kankanaey in Northen Luzon
}

\author{
James Sadagan Guidangen
}

Kalinga State University, Tabuk City, Kalinga, Philippines

Received: 21 Nov 2020; Received in revised form: 18 Jan 2021; Accepted: 06 Feb 2021; Available online: 16 Feb 2021

(C)2021 The Author(s). Published by Infogain Publication. This is an open access article under the CC BY license

(https://creativecommons.org/licenses/by/4.0/).

\begin{abstract}
The study dealt with the child birth rites of the Kankanaeys in Northern Luzon. The Episcopal Diocese of Southern Philippines and the newly born Episcopal Diocese of Davao were established because of their presence since the Kankanaeys migrated to the Southern Philippines.

Kankanaey, as one of the ethno-linguistic groups in the Philippines, embraced, blessed, possessed, practiced rites, rituals, traditions from their ancestors mostly in an oral form. It was the purpose of this study to enumerate, elaborate, and document Kankanaey Child Birth Rites. Descriptive narrative type of research was used in this study, along with photo-documentation, interview, personal observation, and paper recording.
\end{abstract}

Findings reveal that different rites on child birth were performed, rites on this side was not so expensive compared to other ethno-linguistic groups who performed the same. It is therefore recommended that this practices become tools in transmitting such indigenous knowledge to others and further research on this topic is openly welcomed.

Keywords - Kankanaeys, indigenous knowledge, child birth rites, Ngilin, Gobgobbaw, Child naming

\section{INTRODUCTION}

The role of culture in relation to education for sustainable development is one that is crucial. As the Nobel Laureate Wole Soyinka has said "Culture is the primary source of knowledge and understanding of nature begins with local culture. Moreover, local history is expected closest to the people's heart \& consciousness because it reflects their own identity, experiences \& aspirations. It is the interpretative recreation of the past of their locality embracing its political, social, economic \& cultural life. Thus in order to understand and, consequently, appreciate national history, one should first know the history of his own locality \& its contributions to regional \& national development ( Martin, et. al, 2010).

It is at this point then to mention one of the National Commission for Culture and the Arts vision to assist the different cultural communities in identifying their cultural resources, retrieve their traditions, values and ways of governance, and celebrate their culture to empower them to assert their significant presence in the Philippine society. Today, great development in the
Philippines is giving recognition to the different indigenous peoples group or cultural communities.

Padeo (2006) pointed that there were four ethnolinguistic groups in Mountain Province, Kankanaey, Balangao, Baliwon, and Bontoc. The largest group is the Kankanaey occupying the five towns on the western portion of the province Bauko, Besao, Sabangan, Sagada, and Tadian. Next are the Bontocs in the municipalities of Bontoc and Sadanga, then the Balangaos of Barlig and Natonin. Last are the Baliwons of Paracelis where a sprinkling of Ifugaos and Gaddangs resides.

The Kankanaey in the upland areas of Benguet province and belong to the tribal group called "igorots". They are one of the largest tribes in the region. They are a hardworking people in the field of agriculture who are already reached by modern technologies. The Kankanaey build rice terreces which have become sufficient sources of food. The foods of the Kanakanaey are camote, rice, potatoes, and other root crops like tugi and gabi.

The Kankanaey are some of the rest of the best vegetables growers in the Philippines. They innovative ion 
the fields and they practice proven technology like irrigation and the construction of rice terreces. Most of their income comes from tilling the fields. They are also into mining since the Kankanaey territory yields lots of minerals, particularly gold (Asia Missions (AMNET)).

Mountain Province was blessed with beautiful sceneries and rich cultural beliefs and practices that need to be cared, protected, maintained, shared. It is then the aim of this study to present some cultural rites particularly on Child Birth.

\section{REVIEW OF LITERATURE}

GODA (2002). When the baby is born, the husband has to push sharpened bamboo sticks with ginger into the four corners of the roof that are belief to prevent the attack of evil anito. Also, he sets some ginger inside the room where the mother and new baby stay. It is believed that the ginger has special powers to drive away the evil spirits. There is no custom to prepare a special room or a house for women who are going to give birth. The mother should observe ritual seclusion ngilin for three days after the birth.

Belen (2009). She said, on a research of Divine Word College they found out that the most important significance of the Sikki is the naming of the child. The name is after anc ancestor, a relative who possess exceptional traits of acts they wish the child will inherit. The mamaltot (traditional midwife) performs the rite to a newborn baby.

De Raedt, Jules (1993). He found that a few months after a couple have their first child, the parents-inlaw celebrate the happy event. The main feature of the event is the eating of rice cakes. In this particular case, the co-parents-in-law celebrated the occasion together, since they also lived in the same settlement.

Forty nine neighbors contributed glutinous rice for the cakes, through less than forty actually attended the celebration. The celebrants could have solicited contribution from houses in more distant settlements, but found the contributions received thus far sufficient. Each household contributed one to five bundles, and one brother of the husband brought one jar of wine.

Toquero (2009). Based from her, as a people, the Gaddang are loving and caring towards their children, especially their newborn infants. They give protection to their babies through the Mifuldut ritual. The Mifuldut is a prayer-protection, especially for the child and is done three days after birth.

Subagan (2009). She further stressed the upbringing of a Kankanaey baby starts with the proper disposal of the umbilical cord, which is believed to the beginning of real life. An elder called man-ilot, who has knowledge in delivering a child, is responsible for taking care of both the mother and the child. The umbilical cord of the baby is cut, placed in a container covered with soil, and put on top of a bush. The bush symbolically grows with the child and the soil placed on the top of the umbilical cord serves to remind the child to keep his/her feet on the ground; this means the child has to observe humility at all times, which elders always inculcate in the minds of children.

\section{OBJECTIVES}

1. To write and study the existing cultural rites of the Kankanaeys in Northern Luzon particularly on Child Birth.

2. To document and record the Child Birth rites of Kankanaeys in Northern Luzon.

\section{SIGNIFICANCE OF THE STUDY}

This study will benefit the following:

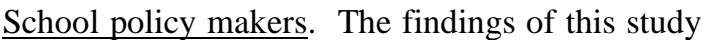
will serve as a baseline data in crafting policies that it will lead to the improvement and implementation of the indigenous people education curriculum and cultural history subjects.

Teachers. They will benefit from this study because they learn traditional practices from other ethic tribes and they will be more competent in handling the indigenous youth if there are problems.

Indigenous community. They shall be benefited from this study because the result will serve as a spring board in their active involvement and participation during cultural activities.

The researcher. He will benefit from this study because he shall understand better the cultural practices of the Kankanaey.

\section{RESEARCH METHODOLOGY}

This descriptive narrative type of research made use of photo - documentation as the prime tool in gathering needed data's supported by an interview, participant observation, mouth-to-paper recording to validate the gathered data from the key informants who were Ritual Practitioner or Performer/Cultural Bearer and the Mensip-ok or Seer.

The researchers coordinated and requested permission from the office of the National Commission on Indigenous People at Bontoc, Mountain Province to 
interview the old folks/cultural bearers/ritual masters and to gather data on the different rites associated with prayers during childbirth. Permission was conducted to further clarify, validate and tabulate the data/information gathered.

This study was conducted in Northern Luzon particularly in the Cordillera Administrative Region during the fiscal year 2017.

It will cover the different rites associated with prayers during childbirth among the Kankanaeys in Northern Luzon, Philippines.

\section{RESULTS AND DISCUSSION}

\section{Child Birth Rites of the Kankanaeys}

\section{A. On Ngilin}

When the baby is born, it is the duty of the husband to fetch and heat water for the wife's bath if necessary. He stays in the house to do errands, wash diapers or clothes used by the mother and baby and cook foods. The baby's mother must have to undergo for ngilin.

Tacwigan (1996) on her study entitled, Ritual Life of Sagada, Mt. Province mentioned that the Igorots in Sagada practice the "Ngilin" throughout the life cycle.

Mrs. Martha Cobebe of La Trinidad, Benguet that Ngilin during death time is similar to this Ngilin after birthing that the caring mother is not allowed to go out and work for her but rather to recover her lost strength and health same to that of the Ilocanos called "Tanggad".

In the Ifugao Community, the mother should observe ritual seclusion ngilin for three days after the birth. No relative or even the husband can enter the house, and the husband has to serve food to his wife at the entrance of the house. The husband has to get water from the irrigation system for one month for his wife and goes to the forest to gather fire woods and it was affirmed by Rev. Ruben Mayyam.

\section{B. Gobgobbaw}

It is performed for the first baby of a couple once the umbilical cord was dropped off. The ritual is either to appease spirits or to seek their assistance. The cultural bearer prayed also for the awaited baby or bestows wishes on it after it is born. A matured chicken will be butchered mixed with salted meat or etag brought by an old men. Before the lunch be served, a cultural bearer prays for thanksgiving and request for the good health of the mother and baby also with his/her fortune.

Fiariod (2001) gave an example of prayer said during the ritual that takes place after the navel of a newly born baby has dropped off.

\section{The Prayer}

At the East there was a mother who delivered a baby. After some days, she got sick. Lumawig came down sent by Kabunyan and said, "You have stomach ache because you did not perform the gobgobbaw." This is what you will say, Lumawig continued. "I'll challenge your feet to be strong and away from all fracture and dislocation. It can jump over any river should there be one to cross Mother and child, we pray for your good health and no stomach ache. All gifts given to you by those who came, let it be sufficient to start a new prosperous life. This, I pray. Amen.

Some years ago, the DLSU website carried a message which said "the Future begins Here" it captures then a futuristic orientation (Gripaldo, 2010). He correlated this message to the painter theory of Restituto E. Embuscado that the true artist must abandon a past-present orientation but rather adopt a present-future orientation which coincides with the response of Mr. John Roman of Magsaysay, Tabuk City that cutting of one's umbilical cord signifies present-future of the child with a successful dreams someday.

\section{Naming}

The rite in naming a newborn baby is performed as soon as its umbilical cord drops off. Relatives within the community are invited. Neighbors and friends participate as a gesture of welcome to the newborn. They bring gifts in kind, such as dried beans, bundles of palay, and provided rice in bitoto container. The men bring etag. A chicken is butchered and cooked with the etag.

Mang-eg, et al(2013) pointed the "Gammid" as a child rearing ritual of the Biga Tribe wherein they are going to accept the child as a new member of the family clan. The meat is preserved by salting, smoking and drying to be brought home by the honored child when he returns with his/her party to the village of his/her birth.

During the preparation, the grandparents decide what name to give to the baby. It is usually the name of a grandparent or a great grandparent that is given the name is announced during the prayer. Kollin (1993) on her study recited a prayer. The prayer runs this way:

We are now giving (name of child) as your name. Rejoice and run fast with it.You the ancestors from both sides of the family, assist (name) and guard him so that he will last with his name until he reaches the time when he will bequeath it to his grandchildren. Sacred spirits dwelling permanently near us, water in Gangod, Matiken and Ood that is fresh and cool then joined in Panta before it flows to the sea.May this family enjoy freshness and coolness as they live together in lasting harmony. 
The people eat and disperse after.

Feliciano (2005) conducted a study entitled "The folk lore of Besao, Mountain Province" that prayers aimed at supplicating or asking Kabunyan for blessings such as fertility or abundance, prosperity, physical and mental being, and long life; thanking Kabunyan for the blessings received; honoring and satisfying ancestral spirits who are believed to be the powerful mediators of the living; and asking to heal the sick or to ward off evil spirits who prey on the living.

\section{- Featuring the Highlights of the Observance of Gobgobbaw}

Native Chicken is preferably butchered intended for this occasion.

Based from reading of the bile it is called "delway" meaning the newly born baby will have a good fortune/future. Mrs Jane Kawi, an 85yrs old rendered the prayer. The prayer goes this way.....

\section{The Prayer}

May the Kabunyan in the East bless this child named Kitkiti(indigenous name) - Israel Jerusalem J. Guidangen (registered name) together with his mother and father. May you help Kitkiti and his parents that their dreams and plans be fulfilled.The good health of Kitkiti, Rodyline and James is humbly asked for this day and the days to come.Kabunyan in the East bless these foods prepared today for our nourishment.Spirits of Kitkiti's ancestors who are at our surroundings please come and join to eat at this residence. All these we ask to our Kabunyan in the East. Amen.

Naming is an expression for belongingness in the Igorot community said by Ms. Martha Sadagan of Ambasing, Sagada, Mountain Province and if should be the beginning of the child to start developing her/his culture rooted identity.

On the other hand, research of the Divine Word College they found that the Tingguians from the province of Abra has the most important childhood ritual which is the naming of the child. The name is after an ancestor, a relative who possess exceptional traits for acts that they wish the child will inherit. The traditional midwife performs the rite to a new born baby.

Mrs. Adelaida Bandonill Paguintolola of Kitkiti gave a cash after the lunch during the GobGobbaw celebration.

\section{CONCLUSION}

This study, although limited in childbirth rites, hopes to have shown a glimpse of the cultural practices of the
Kankanaey people. Based on the findings, the following conclusions can be drawn:

1. Many rites/rituals associated with childbirth are still practiced by the Kankanaeys in Northern Luzon.

2. The implications of these rites are yet to be appraised if not to be appreciated for.

3. For some ethno linguistic tribes in Northern Luzon it is expensive but a great and joyful occasion-gathering of the entire community not only for the clan. However, majority said this rite is not an expensive one.

4. From one generation to another, rites/rituals associated with childbirth is commonly practiced.

5. The Igorot people in Northern Luzon shown a positive values in performing these rites it signifies strengthening family/community ties, cultivating a sense of responsible parenthood and promoting a culture of peace of mind.

\section{RECOMMENDATIONS}

Based on the conclusions made on the study, the following are recommended:

1. The present and next generation should appreciate the sentimental value of these rites.

2. Good cultural practices should be preserved for future generation.

3. Teacher shall integrate cultural practices, values, beliefs if there is a chance to their Social Science subjects in the school.

4. More studies on indigenous culture should be encourage among the community members, students and teachers to have bases, references, and guide for the young generation for them not to be totally forget their roots and cultural practices.

5. Teachers and students who are in the academe shall continue to research cultural and living traditions for future generations.

\section{ACKNOWLEDGEMENTS}

I want to acknowledge the Kalinga State University for giving me the opportunity and sufficient support in order for me to be able to successfully conduct this research.

\section{REFERENCES}

[1] Belen, Yvonne 2009. Cordillera Rituals as a Way of Life.Igorot Cordillera BIMAAK Europe, P.22. 
[2] De Raedt, Jules 1993. Buaya Society. Cordillera Studies Center, University of the Philipines College Baguio, P.55.

[3] Goda, Toh 2002.New Day Publishers.Quezon City, Philippines, P.112.

[4] Gripaldo, Rolando M. 2010. History, Philosophy and Culture. C\&E Publishing, Inc., South Triangle, Quezon City.

[5] Padeo, Elsie S. 2006. Mountain Province. National Commission for Culture and the Arts. Manila.

[6] Fiar-od, Caridad B. 2001. BESAO Traditional Knowledge on Spiritual Beliefs: Its Contributions To Sustainable Development. Mountain Province State Polytechnic College: Bontoc, Mt. Province.

[7] Subagan, Cony C. 2009. National Commission for Culture and the Arts.Intramurus, Manila, P.7.

[8] Toquero, Elena S. 2009. National Commission for Culture and the Arts.Intramurus, Manila, P.30.

[9] Feliciano, Josephina C. 2005. The Folklore of Besao, Mountain Province.Unpublished

[10] Dissertation.Benguet State University, La Trinidad, Benguet.

[11] Gabit, Pablo 1983. A Study of Some Kalinga Cultural Practices and their Significance for the

[12] Education of the Kalingas.Unpublished Master's Thesis.Saint Paul University of the Philippines.

[13] Ismael, Annette B. 2014. The Guilayon Tribe Rituals: From Birth to Death. Unpublished

[14] Master's Thesis.Kalinga-Apayao State College.

[15] Kollin, Agnes S. 1993. The Ethno Cultural Rites of the Northern Kankanaey in the Cordillera.

[16] Unpublished dissertation.Baguio Central University, Baguio City.

[17] Mang-eg, Jonavy T. et al. 2013. Child Rearing Rituals Among The Biga Tribe in Tabuk City,

[18] Kalinga. Unpublished undergraduate thesis.KalingaApayao State College, Tabuk City.

[19] Martin, Jessie Grace S. et al. 2010. Awareness of the Institute of Arts and Sciences Students on Local.History of Tabuk, KASC.

[20] Tacwigan, Joyce Vera S. 1996. Ritual Life of Sagada, Mountain Province. Unpublished Master's Thesis.Saint Paul's University, Tuguegarao City.

[21] Websters Dictionary of the English Language (Chicago:Fergosun Publishing Co., 1967), P.15. 